\title{
On the Linguistic Situation of the Tatar Diaspora in the USA
}

\author{
Guzel Amirovna Nabiullina
}

Alfiya Shavketovna Yusupova

Kazan Federal University, 18 Kremlyovskaya St., Kazan, Republic of Tatarstan, 420008, Russian Federation

\author{
Doi:10.5901/mjss.2015.v6n5s3p298
}

\begin{abstract}
The present article explores the linguistic situation among emigrant Tatars by the example of the Turko-Tatar diaspora in the USA. The cultural and educational work of the Turko-Tatar diaspora contributes to the preservation of the native language, national traditions outside the country as the culture, the language and the religion have played an integral part in preserving the national and cultural image, the lifestyle of the immigrant in a foreign land, in a foreign culture. The language is deemed as the cornerstone of the spiritual culture, a means of cultural cross-fertilization and self-identification. The Tatar diaspora in the USA retains a collective memory of the country of origin as well as striving for self-identification. They possess an enduring identification with the country of origin along with a sense of group unity based on it in order to preserve and develop their language and culture in a foreign environment. The study has confirmed our hypothesis that the linguistic consciousness of the Tatar in America has several features that distinguish it from the linguistic consciousness of Tatars in Tatarstan. At the same time, general views of both groups to certain values can be traced in the linguistic thinking.
\end{abstract}

Keywords: Tatar language, Tatar diaspora, linguistic situation, American Turko-Tatar Association, foreign environment.

\section{Introduction}

The contemporary Tatar language serves as a means of communication for the multimillion Tatar people. Not only is the language widely spread among the Tatar people residing in Tatarstan but also it has dramatically spilt over to a great deal of other regions of Russia as well as foreign countries. According to rough estimates the overall number of Tatars living abroad adds up to 1.100 .000 people; the Tatar diaspora in the far-abroad countries amounting to a little bit over 40.000 people. This is the way it looks it a quantitative sense: 25.000 in Turkey, 5.000 in China, 1.000 in the USA, around 1.000 in Finland, 8.000 in Poland, FRG and other European countries and 1.000 in other Asian countries and Australia (Ganetdinov, http:// tatarica.narod.ru/world/diaspor/tatdiaspor_041203.htm. Date Views 4.01.2015).

The linguistic situation of the Tatar diaspora has been under the fine scrutiny of linguists (2-6) in the last few decades. The necessity for examining the manner in which the native language of the diaspora functions is accounted for by the tendencies observed the modern linguistics that are related to the globalization processes as well as the active interaction between different ethnic cultures Brubaker (2005) \& Dabag \& Platt (1993). Much attention has recently been paid to the language and culture if the Tatar diaspora in China to which the research conducted by A. Yusupova, G. Nabiullina, E. Denmukhametova and G. Mugtasimova has greatly contributed Nabiullina \& Yusupova (2014) \& Yusupova et al. (2013).

Investigating the general mechanisms of the language of the Tatars living far abroad and introducing the results into scientific use is significant both in the terms of the scientific theory and the social culture involved. The article in question that recounts the issues that go with the preservation of the native language and culture of the Tatar diaspora far abroad by the example of the United States has pragmatic applicability for the development of the Tatar cultural linguistics and social linguistics. The target of research is the verbalization of the value of the "Language" in the way of thinking of the Tatars residing in the United States. The sources are as follows: 1) data gained from the published works of different dictionaries; 2) experimental data obtained through examining the associative behavior of the informants that is Kazan Tatars and the representatives of the American Tatar diaspora. A dissertator did the word-for-word translation. Face-to-face meetings, interviews with representatives of the Tatar diaspora during the internship in Milbro, California, were part of the primary methods used to obtain the information required for the research. 


\section{Main Part}

The Tatars lead quite a compact life far abroad having united to form various associations, societies and fraternities. The Turko-Tatar diaspora in the United States is one comprised of Turkic and Muslim peoples who moved from Russia, mainly from the Volga-Ural region and the republics of the former Soviet Union. They adopted the name "Turko-Tatars" in accordance with the resolution of the All-Russian Muslim Congress held in 1917. They have managed to preserve their own culture and the structure of the internal social life in the context of emigration (Ganetdinov, http:// tatarica.narod.ru/ world/diaspor/tatdiaspor_041203.htm. Date Views 4.01.2015).

In the United States, the Tatars who had emigrated from Europe and Asia after the end of the Second World War made up the bulk of the diaspora. The American Tatar Association in the United States was founded based on the Tatar Society of America that emerged in the 1950s in New York. The activities of the of American Tatar Association focus on the cultural direction (a lot of famous Tatar musicians, scientists, chess-players and other distinguished persons ended up there after the war and in the 1960-70s).

On the west coast of the USA, the American Turko-Tatar Association (ATTA) is located. It is also engaged in cultural and educational activities. After the First World Congress of Tatars had been held in the United States a number of young entrepreneurs from Tatarstan left for America at the invitation of the American Tatars (Ganetdinov, http:/l tatarica.narod.ru/world/diaspor/tatdiaspor_041203.htm. Date Views 4.01.2015).

There are two groups of Tatars in America nowadays; one representing the old wave of immigration and one accounting for the latest wave. Each of these ethnic groups has its own history of settlement and residence in the America. The road that the first group got to walk in America was very long and rocky. Most members of the group fled from the Bolsheviks after the collapse of Tsarist Russia just to settle down in China, Korea and Japan. In 1949 to 1951 , they fled from the communists to Australia, Turkey and Japan. The people who were part of the old wave include such prominent people as Dr. Sait Salah, a nuclear engineer; professor Onur Senarslan who lives in Washington, DC; Yulai Shamiloglu, a professor-turcologist Mahmutov (2012).

As mentioned above the American Turko-Tatar Association (hereinafter ATTA) in the United States was founded based on the Tatar Society of America that emerged in the 1950s in New York. The first president was elected in 1927. His name was Hairullah Yenikeeff. Over the years, the Tatar Association in New York has had many leaders that are enumerated here: Rashid Huseinoff, Esmail Akchurin, Hamid Rashid, Garip Sultan, Rifat Salah, Ildar Agish, Rustem Borluca and many others. Today Saide Haci holds the position of the chairman of the ATA. The activities of the American Tatar Association center upon the cultural direction since a lot of famous Tatar musicians, scientists, chess-players and other distinguished persons ended up there after the war and in the 1960-70s.

The American Turko-Tatar Association (ATTA) is located on the west coast in San Francisco that is also engaged in cultural and educational activities. It has changed many leaders such as Farid Sprat, Orkyya Safa and Orkyya Mansour. Currently the position is held by Cuneyt Capanoglu (The official website of the American Turco-Tatar Association / URL http://attasf.org/home/atta-history.php).

The first Tatars arrived in New York during the Russian Revolution times. The second group that went to China would start relocating to America in1925 to1935. This year, the American Tatar Association in New York celebrates its 86th anniversary. After World War II, many compatriots who had been held prisoner in Germany started arriving. In 1950 about 50-60 people out of those who had emigrated to China, Japan and Turkey arrived in New York. Today the American Tatar Association in New York is comprised of only 120-130 people.

Those who came from Japan and Turkey in 1960 formed the American Turko-Tatar Association (hereinafter ATTA). Their numbers were comprised of about 120 families, more than 300 people. In 1964, the current headquarters of the ATTA were purchased. Nowadays the ATTA membership adds up to 232 people (The official website of the American Turco-Tatar Association / URL http://attasf.org/home/atta-history.php).

Initially the main unifying thread was a single religion - Islam. Those immigrants who lived in Japan and China tried to preserve the language and culture to pass it on to their children, the future generation. What is also interesting is that the language of the Tatars who grew up in China and Japan before moving to America is different. The language spoken by the Tatars who lived in China is more like a mishar version of the Tatar language; the language of the Japan Tatars being close to the Kazan dialect. This is explained by the fact that in Japan a printing-office was founded under the guidance of Mr. Kurbangaliev in 1928, which reprinted all publications produced in the 1890-1915 in Kazan. Cuneyt Capanogluu, the chairman of the ATTA, recollects that the books published in Tokyo could be divided into the following groups:

1. Religious books - the Koran, etc.;

2. Books on literature, fiction; 
3. Textbooks, historical literature, children's literature (Letter to C. Capanoglu of May 3, 2012).1. Religious books - the Koran, etc.

The Turko-Tatar diaspora in the US rallies and unites cultural and religious ties. The representatives of the Tatar diaspora use Tatar and Turkish languages, both orally and on paper, based on the Latin alphabet in communicating with each other at home and at various meetings. For disseminative purposes, all information in Cyrillic letters is changed to the Latin font. The monthly "Bulletin of the American Turko-Tatar Association" is published in two languages: English and Tatar (in Latin).

According to the data presented on the official website of the ATTA (http://www.attasf.org/) the history of the foundation of the Association is as follows: "... Upon arrival in San Francisco, the Tatars were a small group amid the multiple nationalities populating California. A few people decided to officially organize a Tatar community in order to preserve the traditions of their ancestors, namely, the language, the culture and the religion. It was on May 15, 1960 that thirty people gathered to hold the first official meeting of the community and determine plans for the future in the building of "Odd Fellows Hall" in Burlingame. On this day, it was determined that the organization could be founded as an American Turko-Tatar Association pursuing the goal of preserving the cultural, ethnic and religious interests of the local Tatar community. In addition to that, officials were elected, membership issues addressed and laws established (The official website of the American Turco-Tatar Association / URL http://attasf.org/home/atta-history.php).

Later on in 1964, the ATTA acquired a building for holding meeting with the members of the community putting great efforts into setting the stage for fruitful and successful work. The ATTA building endearingly called "Bina" (Tatar for building, house) had a large conference room, office/library, two storage rooms, a kitchen and two bathrooms. The meeting room could accommodate 80 people. Thanks to the workers knocking themselves out, all repairs and restoration work were finished in one and a half years. Ever since then, Bina has hosted countless religious and cultural events organized both for the members of the community and the public.

The ATTA mission is to operate for the benefit of society and the Turko-Tatar heritage and culture through the promotion and support of cultural, educational, religious and charitable activities; support the interests of the community in social welfare and cooperation with other organizations in the cultural, civic and social development.

The Tatars have remained true to their national cuisine; they keep in touch and correspond with their compatriots living in Turkey and Finland (Akhmetova, 2004, p.154). The young seek to start a family with the representatives of their people looking for soul mates among the Tatars living in Turkey, Finland, Australia and in Tatarstan. But many of the children of the immigrants Tatars marry Americans thereby getting assimilated into the cultural environment. It is appropriate to cite the speech of Zohra Tahir, the Chairman of the Tatar community in Finland containing the following instructions for the youth:

- Firstly, speak the native language in a beautiful way thus showing respect and love to the language; remain mindful of the customs and rituals of your ancestors and do not detach yourselves from the rich spiritual and cultural traditions of your people;

- Secondly, refrain from marriage with people of another nationality remembering that it can lead to the destruction of national unity;

- Thirdly, remain faithful to your religion (Islam) and respect the canons adopted in the Muslim world ("News mahalla 1955, №10-11, p. 20) (Ganetdinov, p. 35).

It seems that nowadays in America there are two main Turko-Tatar Associations that have come a long and difficult path whilst uniting and preserving the language and culture of their people. On the east coast, one has the AAT (Association of American Tatars) with the ATTA on the west coast. There are Tatars scattered all over America that are united by social networks and Internet communities.

The foundation of the American Turko-Tatar Association was a necessity. It continues to exist enriching its 50-year history. Over that period, much has changed in the composition of the American Turko-Tatar Association but over the years the association has evolved. Thanks to its prominent members, it succeeds in preserving and transmitting the national spirit to its descendants and cooperating with compatriots.

People speaking the same language and sharing the same culture are supposed to have common features that would distinguish them from the representatives of other cultures. It is through the language and thanks to the language that cultures form the image of the world in the eyes of the representatives of a particular ethnic group and pass this image from generation to generation. It is due to the generality of the world image that the socialization of individuals occurs and their self-identity comes to be.

It seems to us that the issue of studying and preserving the native language is one of the main problems of the Tatar diaspora. The language allows emigrated families to keep their children in touch with the Turko-Tatar culture and that of their country. Knowing your roots allows one to significantly better absorb the culture and values of a society new 
to one. The preservation of national traditions is the main task of every nation. The Tatar people have many national traditions so the Tatars living in America seek to preserve and pass their knowledge on their offspring, share their culture with the representatives of other nationalities.

The diversity factor is slightly different in these groups of respondents which was to be expected; the Tatars living abroad being more unanimous, answers varying in terms of the depth of meaning. The respondents in the United States give a characterization of "Tatar" not abstractedly but through the emotions and concrete ideas based on personal experience: «Tugan telem, äti-äni, äbi-babam tele, berençe äytkän süzlärem, berençe işetkän äkiyätlärem , fikeruylarim, ömetlärem ... "; (Native language, the language of my parents, grandparents, my first words, the first tale, my thoughts, hopes); «Ey tugan tel, ey mator tel, Etkem enkemneng tele! .. Ol tel bezneng kemlegebezneng sifate, barlegebezneng isfate ham ber millat bolep bashkalar katarenda tek turewebezneng qurale. Tatar tele tamerenda Tatar kane bolganlar uchen bik qimmatle ber hazinader »; (An indicator of who we are, a very precious treasure); «Tatar tel äitkäch, mina ing berenche 'ailä' iskä töshä. Tatar tel = ailä. Yäsh bulganda kuberäk Englishchä söyli idem, ä uz ailäm bulgach, Tatar telgä kuchtem, bötönläy. Bezneng tora torgan cirdä äz Tatarlar yäshägäch, Tatar tele bezne ayirta bashkalardan. Bu minemcha bik positiv närsä. Yaratam dip Tatar tele bezne 'unique / uzenchälekle' tota. (I associate the Tatar language with family. The Tatar language equals family. In my youth, I used to speak in English most of the time but as soon as I had started my own family, I almost completely switched over to Russian. The Tatar language encloses us from the others because there are very few Tatars living in our country. I believe it is a very positive development. The Tatar language is unique and special); "The Tatar language taught me the Tatar culture, famous Tatar poets, most importantly, the Tatar history that I am proud of. I feel comfortable when I speak it. Tatar songs help me to get rid of my stress".

It should be noted that to the representatives of the Tatar diaspora in America the Tatar language which embodies certain tenets of the ethnic culture, primarily tends to symbolize the ties with the traditions, history and the people. Tatar is the language of their ancestors and associated with family that points to the language localization in a foreign environment where the main language of communication is English.

The discrepancy in the perception of the "Tatar language" among those interviewed can be traced in the reply of one of the respondents who notes the supremacy of the English language: "Not much. I have a high school diploma because of the English language. I have a college education because of the English language. I have a job because of the English language. I own a car, a house, savings in the bank because of the English language".

It should be emphasized that the replies of the Kazan Tatars feature a large number of the following valuemotivational associations: tugan tel (home), matur (beautiful); soulful; monly; melodic; bai (rich) and at the same time difficult; so Tatar; occasionally funny. The Tatars living in Tatarstan note that the Tatar language is a state one while for the Tatars in America it primarily remains the language of the soul, the language of culture - "It enhances and plays an important role in my cultural, religious and ethnic heritage". Although the Tatar language is not a state language in America but for the Tatars it is the language that they hear listening to and enjoying Tatar music, theater performances and television programs; listen to Juma sermons in the Tatar language on the Internet and use it as a means of sharing their achievements, mistakes, information and resources with other Tatar communities.

According to our survey, the Tatar language for the two groups primarily qualifies as a 'native tongue and mother tongue". The Kazan Tatars are more laconic and abstract in their responses because they have no lack of language as they are free to speak Tatar in everyday life as well as having free, daily access to the Tatar culture, much different from the Tatars in America.

As we have already noted, the members of the diaspora being carriers of dual identity live in two cultures simultaneously. This being said, the diasporas miraculously retain their ethnic and cultural boundaries for various reasons. The diasporas generally try to keep the ethnic identity contrasting their kind with others. When one has lived with others in the same area for a prolonged period of time there comes the inevitable process of acculturation which affects the diaspora culturally in different ways.

By analyzing different sources, we have concluded that the Tatar diaspora in America is something united and whole despite its territorial fragmentation (the western part of America) and seeks strictly to adhere to the culture of the country of origin that is the Tatar culture. This is made possible by the Tatar language, which is the only unifying language for the Tatars in a foreign environment.

According to research materials, despite not being an official language the Tatar language is highly valued on the household level and within the diaspora community firstly, as the language of Tatar culture, and secondly, as a means of communication between the representatives of the Tatar nationality worldwide. The Tatar language is the primary factor in the determination of belonging to the Tatar nation itself among the members of the Tatar diaspora in America. 


\section{Conclusion}

Summarizing, we can say that the Tatar language is a link that can miraculously preserve cultural exchange even through the millennia passing from generation to generation. The Tatar language holds one of the primary places in the national language picture of the world of Tatars both living outside of their historical homeland and in Tatarstan.

1. Tatar-speaking inhabitants of America can be considered a diaspora to the full extent, one that is aware of its identity, and tries to preserve and pass it on to future generations.

2. The status of the Tatar language among the older generation on the mundane level is quite high, whereas communication in English dominates among youth.

3. Language consciousness of Tatars in America can be characterized as that of a diaspora in the sense that the picture of the world of Tatars living in this country is definitely characterized by common features.

They have kept the continuity of language and culture from generation to generation for a century, despite the remoteness from their historical homeland and different countries of residence. On the one hand, the linguistic picture of the world of Tatars inhabiting America today is very similar to the picture of the world of the modern Tatars of Tatarstan. On the other hand, the territorial isolation of the Tartars, the inhabitants of America from the country of origin, nevertheless led to the preservation of cultural features characteristic of Tatar culture in whole, and sometimes of a single generation of Tatars (XIX century).

Summarizing, we can say that the diaspora consciousness of the Tatars in America is characterized by:

- The desire to preserve the Tatar culture and language while remaining open to the foreign culture;

- Stability of the basic components of the Tatar language picture of the world with the presence of elements of influence of another (American) picture of the world;

- The Tatars living abroad are unanimous; their answers being notable for depth of meaning through the emotions and concrete ideas based on personal experience.

Thus, the Tatar diaspora abroad retains a collective memory of the country of origin as well as striving for selfidentification. They possess an enduring identification with the country of origin along with a sense of group unity based on it in order to preserve and develop their language and culture in a foreign environment.

The prospects of this study appear to become further research of the linguistic worldview of the diaspora in general and the Tatar diaspora in particular. It is interesting to examine the specific features of the linguistic consciousness of Tatars living in different regions and republics of the Russian Federation and both near and far abroad countries. Our study is of a more general nature therefore in the future a deeper study of certain values in the linguistic worldview of Tatars in different countries appears to be of interest.

\section{References}

Ganetdinov, R. Tatars in far abroad countries: countries, population, organizations / http:// tatarica.narod.ru/world/diaspor/tatdiaspor_ 041203.htm. Date Views 4.01.2015

Sadiykova, L.R. (2011). Preservation of ethnic-cultural identity of the "Turkic-Tatar" diaspora in the USA. Ufa science centre herald, RAS, 3-4: $81-87$.

Mahmutov, Z.A. (2012). Ethnic-cultural processes in environment of Tatar diaspora of Kazahstan. J. Bulletin of the Chuvash university, 4: $37-39$

Gazizova, E. and. Fayzulaeva, (2010). M.P. Tatar diaspora in Latvia. J. Bulletin of Kazan State university of culture and arts, 2: 101-104.

Shovgenin, A.N. (2008). Theoretical foundations of studying Diaspora languages. J. VolGU Bulletin, Ser. 9, Young Scientists Research, 7: 43-45.

Safran, W. (1991). Diasporas in Modern Societies: Myths of Homeland and Return. Diaspora. Volume 1: 148-149.

Brubaker, R. (2005). The "diaspora" diaspora. J. Ethnie and racial studies. N.Y. Volume 28: 1-19.

Dabag, M. and Platt, K. (1993) Diaspora and the collective memory. For the construction of Collective Identities in the Diaspora. Bochum: 117-145.

Nabiullina, G.A. and Yusupova, A.Sh. (2014). Tatar-Chinese language interactions (based on Chinese loanwords in the speech of the Tatar diaspora living in modern China). Journal of Language and Literature. Volume 5(3): 241-245.

Yusupova, A.Sh. et al. (2013) Features of the language of Tatars living in China J. Middle-East Journal of Scientific Research. Volume 17 (2): $168-172$.

The official website of the American Turco-Tatar Association / URL http://attasf.org/home/atta-history.php.

Akhmetova, Y.M. (2004) The dialect of Tatars of Finland: in comparative historical aspect: dissertation... by candidate of Philological Sciences. Kazan. 